\title{
Ecophysiology of young stems (cladodes) of Opuntia ficus-indica in wet and dry conditions
}

\section{Ecofisiología de tallos jóvenes (cladodios) de Opuntia ficus-indica en condiciones húmeda y seca}

\author{
Eulogio Pimienta-Barrios*, Julia Zañudo Hernández, Alejandro Muñoz-Urias \& Celia Robles- \\ Murguía
}

Departamento de Ecología, Centro Universitario de Ciencias Biológicas y Agropecuarias, Universidad de Guadalajara, 45110, Zapopan, Jalisco, México.

*e_pimienta@hotmail.com.

\begin{abstract}
The rates of instantaneous net $\mathrm{CO}_{2}$ uptake were measured every $2 \mathrm{~h}$ over $24 \mathrm{~h}$ periods in young stems (cladodes) of Opuntia ficus-indica (L.) Miller those were well-watered or exposed to drought during the Spring. Stem relative water content was also measured. Young cladodes showed Crassulacean acid metabolism (CAM). Spring drought reduced daily net $\mathrm{CO}_{2}$ uptake and watering sustained it. A dry environment affected the expression of CAM phases in young cladodes, curtailing $\mathrm{CO}_{2}$ uptake in the late afternoon (phase IV of CAM) more than that in the early morning (phase II) or at night (phase I). Young cladodes maintain positive values of carbon gain in the dry spring, notwithstanding the low capacitance of their water-storage parenchyma. Cladodes showed rapid recovery of photosynthesis and relative water content in response to scarce rain that interrupted the drought at the end of May. Both the instantaneous rate of $\mathrm{CO}_{2}$ uptake and the daily carbon gain of young cladodes increased significantly in June, after the plants received considerable rainfall. The photosynthetic efficiency of young cladodes was not far from the values observed in mature cladodes.
\end{abstract}

KEYwords: Crassulacean acid metabolism, daily net $\mathrm{CO}_{2}$ uptake, drought, Opuntia, relative water content.

\section{RESUMEN}

Las tasas de asimilación neta de $\mathrm{CO}_{2}$ fueron medidas cada $2 \mathrm{~h}$ por 24 h en tallos jóvenes (cladodios) de Opuntia ficusindica (L.) Miller que estaban regados o expuestos a sequía en la primavera. También fue registrado el contenido relativo de agua. Los cladodios jóvenes mostraron metabolismo ácido de las crasuláceas (MAC). La sequía en la primavera redujo la asimilación neta diaria de $\mathrm{CO}_{2}$ y el riego la mantuvo. El ambiente seco afectó a la expresión de las fases de MAC reduciendo la asimilación de $\mathrm{CO}_{2}$ al final de la tarde (fase IV de MAC) más que por la mañana temprano (fase II) o por la noche (fase I). Los cladodios jóvenes mantuvieron valores positivos de ganancia de carbono en la primavera, no obstante su escasa cantidad de parénquima de almacenamiento de agua. Los cladodios jóvenes mostraron recuperación rápida de la fotosíntesis y en el contenido relativo de agua en respuesta la escasa lluvia que interrumpió la sequía al final de mayo. La tasa instantánea de asimilación de $\mathrm{CO}_{2}$ y la ganancia diaria de carbono de los cladodios jóvenes aumentaron significativamente en junio, después de que las plantas recibieron una cantidad sustancial de lluvia. La eficiencia fotosintética de cladodios jóvenes es cercana a los valores observados en cladodios maduros.

Palabras clave: Asimilación neta diaria de $\mathrm{CO}_{2}$, contenido relativo de agua, Opuntia, metabolismo ácido de las crasuláceas, sequía.

\section{INTRODUCTION}

Our understanding of the metabolic control and functional significance of CAM has mainly been derived from studies of the mature photosynthetic organs of species of the Crassulaceae and Cactaceae, whereas young organs have received little study (Winter et al. 2008). Gas exchange in opuntias has been studied extensively in mature plants (Szarek \& Ting 1975, Hanscom \& Ting 1978, Nobel et al. 2002), but there have not been many studies of gas exchange in young stems (cladodes) (Acevedo et al. 1983, Wang et al. 1997, Winter et al. 2008). Except for observations realized 
by Acevedo et al. (1983), the majority of the studies on gas exchange byyoung cladodes were performed undercontrolled environmental conditions (light, temperature, and soil water content) that were favourable for plant development; thus, studies of gas exchange in young cladodes under controlled conditions avoided the stressful conditions that prevail in Spring in the field. Here, we report the ecophysiological responses of young cladodes of Opuntia ficus-indica under both well-watered and dry conditions in the Spring season and their recovery to drought after rains. Because young cladodes had a small water-storage parenchyma, we hypothesized that the susceptibility of young cladodes to drought will increase parallel to the decrease in soil water content, since their low water storage capacity will not be sufficient to buffer the effects of spring drought stress on young cladodes. Conversely, watering in the Spring dry season will mimic the effect of succulence observed on the mature cladodes, buffering the effects of drought stress for young cladodes.

\section{MATERIALS AND METHODS}

\section{Plant AND SITE DESCRIPTION}

Opuntia ficus-indica is a perennial shrubby cactus 1.0 $2.0 \mathrm{~m}$ tall, with a poorly defined trunk made up of thick, elliptical green cladodes. This species is widely distributed on the semiarid lands of central Mexico (Bravo-Hollis 1978). Young stem segments (cladodes) of O. ficus-indica are used as a green vegetable throughout Mexico and in the southwester United States (Nobel 1994). Measurements were made during the Spring and early Summer of 2004 at an experimental field of the Departamento de Ecología of the Universidad de Guadalajara. The site is in central Jalisco, México, at $20^{\circ} 5^{\prime} \mathrm{N}, 103^{\circ} 32^{\prime} \mathrm{W}$ and $1420 \mathrm{~m}$ above sea level. The climate is temperate-subtropical. The average annual rainfall is $950 \mathrm{~mm}$, and the average annual temperature $19^{\circ} \mathrm{C}$.

\section{Climatic AND MiCRoclimatic DATA}

Rainfall data were obtained from a weather station maintained by the Fifth Military Base of the Mexican Air Force, located $5 \mathrm{~km}$ from the study site. On the dates of gas exchange measurement, the photosynthetic photon flux (PPF, wavelengths of 400-700 nm) was recorded hourly from sunrise to sunset with a LI-250 quantum sensor (LICOR, Lincoln, NE, USA) and then integrated to get the total daily PPF Both air temperature and relative humidity were recorded hourly using a mercury thermometer and a 63-101 digital humidity gauge (Radio Shack, Los Angeles, CA).

EXPERIMENTAL CONDITIONS

Sixty mature 12-month-old cladodes of Opuntia ficus-indica
(L). Miller (Cactaceae) averaging $35 \mathrm{~cm}$ long, $19 \mathrm{~cm}$ wide, and $2.0 \mathrm{~cm}$ thick were planted on March 3, 2004, in plastic pots $(19 \mathrm{~L})$ filled with a vermiculite/sand mixture $(1: 1, \mathrm{v}$ : v). Beginning on March 4, 30 mother cladodes received $5 \mathrm{~L}$ of water per pot each week, until rainfall began (wet conditions), whereas the other 30 mother cladodes were not watered (dry conditions).

\section{Morphological obSERVATIONS}

Eight young cladodes and six mature cladodes were collected on March 25, 2004 from a cultivated plantation at Nextipac, Jalisco, Mexico, and used for cladode measurements of thickness of the cuticle, chlorenchyma and the water storage parenchyma, in hand-cut transverse sections stained in $0.5 \%$ (w/w) aqueous toluidine blue (Berlyn \& Miksche 1976) and viewed at $10 \times$. Stomata frequency was obtained using hypodermal peels examined at $40 \times$ using bright field optics with a Zeiss Sinoptic microscope (Oberkochen, Germany).

\section{SOIL WATER CONTENT}

Soil water content was determined on the dates of gas exchange measurement from the centre of the root zone for ten soil samples of $50 \mathrm{~g}$ each (at depth of $10 \mathrm{~cm}$ ) that were dried at $105^{\circ} \mathrm{C}$ to constant mass. Values are expressed as percentage water content: [(fresh mass - dry mass)/fresh mass] $\times 100$ (Torres 1984).

\section{Plant WATER STATUS}

The young cladodes relative water content (RWC) growing on mature cladodes in both wet and dry conditions was determined between 10:00 h to 11:00 h on May 14 and 24 and June 25 for 5 segments $(0.9 \times 0.9 \mathrm{~cm})$, by immediately determining their fresh mass and then oven drying at $80^{\circ} \mathrm{C}$ to constant mass. The RWC was then calculated (Koide et al. 2000).

\section{Gas EXCHANGE MEASUREMENTS}

The rates of instantaneous net $\mathrm{CO}_{2}$ uptake (Pn) were measured in young cladodes every $2 \mathrm{~h}$ over 24 -h periods on April 22-23, May14-15, May 28-29, and June 25-26 2004 with a LI-COR LI-6200 portable photosynthesis system. A $0.25 \mathrm{~L}$ leaf chamber was modified by replacing the distal half-cylinder with a narrow opening $(2 \times 4 \mathrm{~cm})$ lined with a closed-pore foam gasket that was firmly pressed against an approximately southwest facing surface of the cladodes. Total daily net $\mathrm{CO}_{2}$ uptake was obtained by integrating the instantaneous rates over $24 \mathrm{~h}$.

\section{Statistical ANALYsis}

Data were analysed using ANOVA (Zar 1999); means were separated by a least significant difference (LSD) test (Little $\&$ Hill 1975). Data are presented as the means \pm S.E. $(n=$ number of measurements). 


\section{RESULTS}

Climatic AND Microclimatic CONDITIONS

The total rainfall throughout the study period was $326 \mathrm{~mm}$. Rainfall did not occur in March or April, and the plants did not receive rains until late May. The rains increased significantly in June (Fig. 1). Under dry conditions the soil water content was low on April 22-23 and May 1415 , before rainfall began. Once rains began in late May, the soil water content under the dry conditions was higher on May 28-29 and June 25-26. Under the wet conditions the soil water content was over $25 \%$ from April 22-23 to June 25-26. The total daily PPF was higher on May 28-29 than on any of the other measuring dates (April 22-23, May 14-15, May 28-29 and June 25-26). The mean day/night temperatures were lowest for April 22-23 and May 14-15 and highest for May 28-29, decreasing on June 25-26. The mean day/night relative humidity was highest on June 2526, lowest on May 14-15 and intermediate on May 28-29 and April 22-23 (Table I).

YOUNG CLADODES GROWTH

Young cladodes showed the highest rates of growth in March under both the wet and dry conditions $\left(0.27 \mathrm{~cm} \mathrm{~d}^{-1}\right)$ and their rates of growth were not different $(\mathrm{P}=0.4878)$. In April, the rates of growth of young cladodes decreased to $0.20 \mathrm{~cm} \mathrm{~d}^{-1}$ under the dry condition but the reduction was small $\left(0.26 \mathrm{~cm} \mathrm{~d}^{-1}\right)$ under the wet conditions. From May to June, the rates of young cladodes growth declined to 0.03 $\mathrm{cm} \mathrm{d}^{-1}$ under both the wet and dry conditions (Fig. 1).

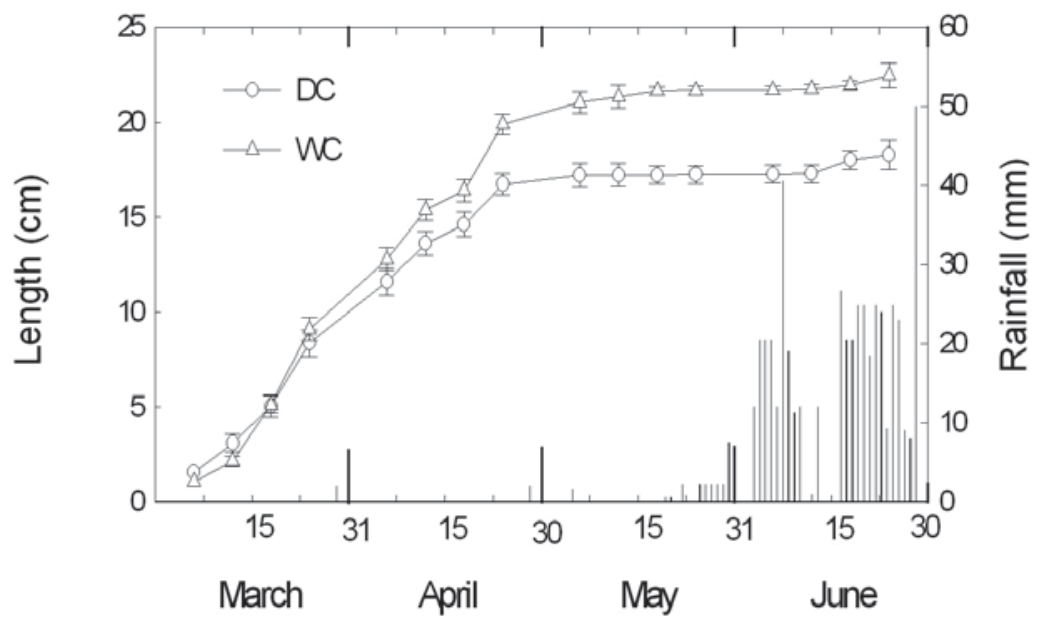

FIGURE 1. Elongation of developing daughter cladodes of $O$. ficus-indica under wet and dry conditions and daily rainfall. Values are means $\pm \mathrm{SE}$ ( $\mathrm{n}=12$ cladodes, six from each treatment for cladode growth).

FIGURA 1. Elongación de cladodios jóvenes en desarrollo de O. ficus-indica en condición húmeda y seca y precipitación pluvial diaria. Los valores son promedios $\pm \mathrm{EE}$ ( $\mathrm{n}=12$ cladodios, seis para cada tratamiento para crecimiento de cladodios).

TABLE I. Soil water content under wet and dry conditions, averages day/night temperature and relative humidity and total daily photosynthetic photon flux (TDPPF).

TABLA I. Contenido de agua en suelo bajo condiciones húmeda y seca, promedios de temperatura día/noche y humedad relativa diaria y total diario del flujo de fotones fotosintéticos (TDPPF).

\begin{tabular}{lccccc}
\hline Date & $\begin{array}{c}\text { Soll water content } \\
(\%)\end{array}$ & $\begin{array}{c}\text { Day/Night } \\
\text { TEMPERATURe } \\
\left({ }^{\circ} \mathrm{C}\right)\end{array}$ & $\begin{array}{c}\text { Day/Night } \\
\text { RELATIVE Humidity } \\
(\%)\end{array}$ & $\begin{array}{c}\text { TDPPF } \\
\left(\mathrm{mol} \mathrm{m}^{-2} \mathrm{~d}^{-1}\right)\end{array}$ \\
\hline April 22-23 2004 & 27.0 & 4.2 & $22 / 13$ & $48 / 89$ & 46 \\
May 14-15 2004 & 25.0 & 2.5 & $23 / 14$ & $23 / 45$ & 48 \\
May 28-29 2004 & 28.0 & 8.0 & $27 / 20$ & $34 / 59$ & 60 \\
June 25-26 2004 & 30.0 & 20.0 & $23 / 17$ & $65 / 91$ & 46 \\
\hline
\end{tabular}


MORPHOLOGICAL OBSERVATIONS

The average cuticle thickness of mother cladodes of O. ficus-indica was 6.5 -fold $(28 \pm 2.3 \mu \mathrm{m})$ that young cladodes $(4.3 \pm 0.62 \mu \mathrm{m})$. The stomatal frequency was lower for mother cladodes $\left(22 \pm 1\right.$. Stomata. no. $\left.\mathrm{mm}^{-2}\right)$ than for young cladodes $\left(52 \pm 4.5\right.$ Stomata. no. $\left.\mathrm{mm}^{-2}\right)$. Both the chlorenchyma and the water storage parenchyma were thicker in mother cladodes than young cladodes $(6.0 \pm 1.5$ $\mathrm{mm}$ vs. $1.50 \pm 0.16 \mathrm{~mm}$ and $20 \pm 3.0 \mathrm{~mm}$ vs. $2.5 \pm 0.16$ $\mathrm{mm}$, respectively).

\section{RELATIVE WATER CONTENT}

The RWC for young cladodes on May 14 was statistically higher under the wet condition than the dry condition $(\mathrm{P}=$ 0.004). When scarce rains occurs after the middle of May the RWC in young cladodes increased under both the dry and wet conditions, and the RWC values were not different. On June 25, the RWC in young cladodes showed a small increase under the wet condition and a slight reduction under the dry condition (Fig. 2).

DAily PATTERnS OF $\mathrm{CO}_{2}$ UPTAKE

For both the wet and dry conditions, the principal period of positive net $\mathrm{CO}_{2}$ uptake in young cladodes for all the dates of measurement was at night (phase I, in the terms of Osmond 1978), accounting for $84 \%$ of net $\mathrm{CO}_{2}$ under the wet condition and $82 \%$ of net $\mathrm{CO}_{2}$ under the dry condition. Daytime uptake of $\mathrm{CO}_{2}$ during Phase II (early morning) was observed for all the dates of measurement under both the wet and the dry conditions; however, Phase IV (late afternoon) was substantially curtailed on April 22-23 under both the wet and dry conditions and on May 14-15 under the dry condition. Positive values of Pn in phase IV occurred on May 14-15 and 28-29 and June 25-26 under the wet condition (Fig. 3 b, c, d) and on May 28-29 and June 25-26 under the dry condition (Fig. 3 g, h). Watering increased both the daytime and nighttime periods of positive net $\mathrm{CO}_{2}$ uptake as well as the Pn rates (Fig. 3 b, c, d). Under the dry condition the highest values of Pn occurred after midnight for all measurement dates (Fig. 3 e, f, g, h), whereas under the wet condition, the highest Pn was measured after midnight on April 22-23 (Fig. 3 a), at the beginning of the night on May 14-15 (Fig. 3 b) and close to midnight on May 28-29 and June 25-26 (Fig. 3 c, d). The shortest time of positive net $\mathrm{CO}_{2}$ at night $(8 \mathrm{~h})$ was observed on May 14-15 under the dry condition (Fig. 3 f).

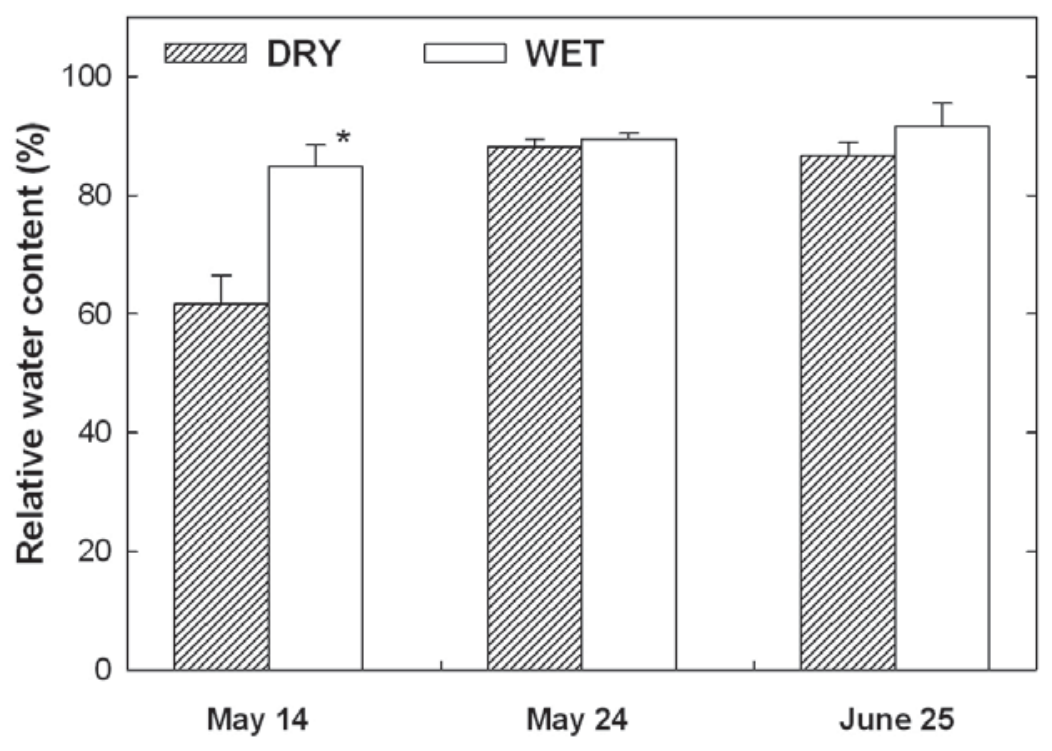

FIgURE 2. Relative water content for young cladodes of O. ficus-indica under wet and dry conditions on May 14, May 24 and June 25. Values are means $\pm \mathrm{SE}$ ( $\mathrm{n}=6$ plants). Asterisk above the bar indicate statistically significant difference at $\mathrm{P}=0.004$ by LSD multiple test.

Figura 2. Contenido relativo de agua para cladodios jóvenes de $O$. ficus-indica en condiciones húmeda y seca el 14 de mayo, 24 mayo y 25 junio. Los valores son promedios $\pm \mathrm{EE}$ ( $\mathrm{n}=6$ plantas). $\mathrm{El}$ asterisco sobre las barras indican diferencias estadísticamente significativas a $\mathrm{P}=0,004$ en la prueba de DMS múltiple. 
Wet condition

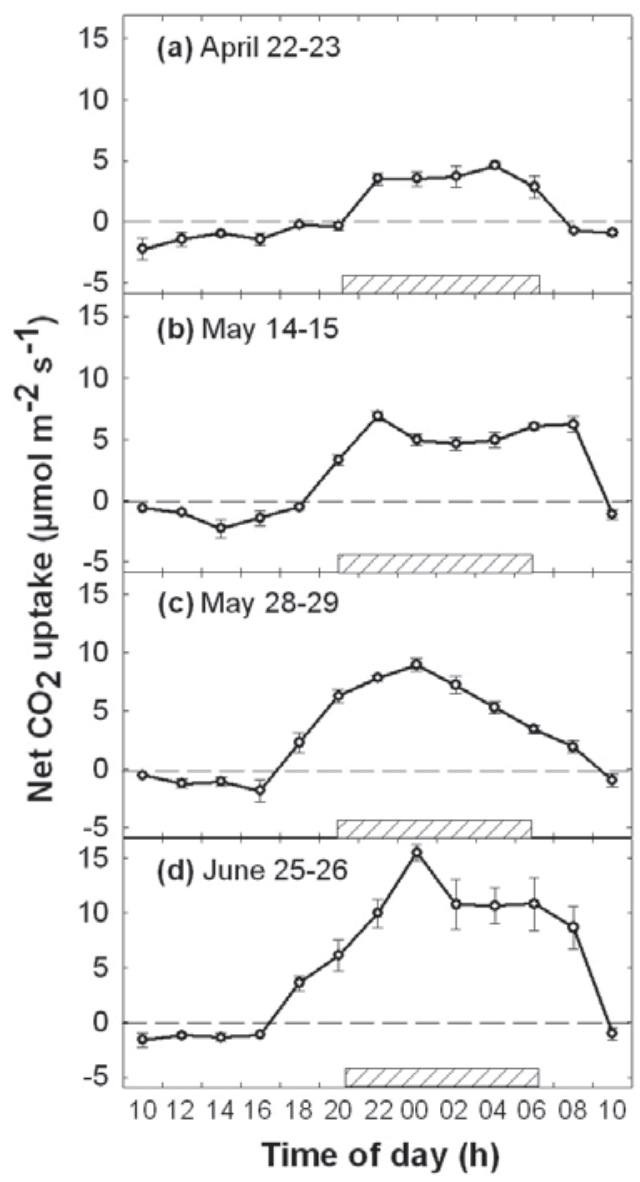

Dry condition

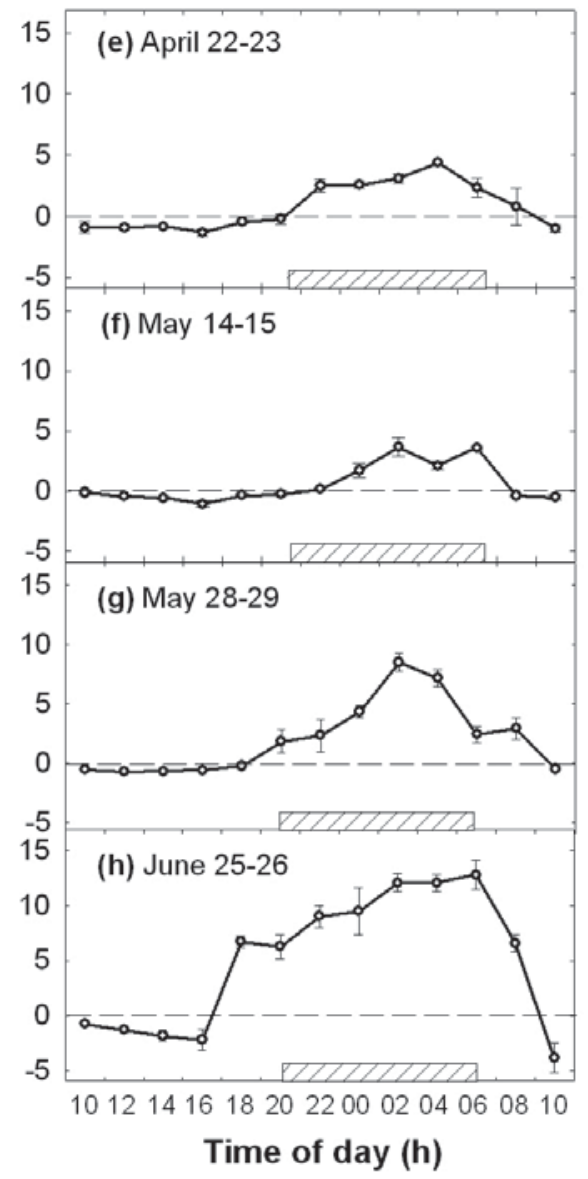

Figure 3. Net $\mathrm{CO}_{2}$ uptake rates over 24 h periods for young cladodes of $O$. ficus-indica on April 22-23, May14-15, May 28-29, and June 25-26 under wet and dry conditions. Hatched bars indicate night. Values are means \pm SE ( $n=6$ plants).

Figura 3. Tasas de asimilación neta de $\mathrm{CO}_{2}$ por periodos de más de 24 h en cladodios jóvenes de $O$. ficus-indica el 22-23 de abril, 14-15 de mayo, 28-29 mayo, y 25-26 de junio en condiciones húmeda y seca. La barra sombreada indica la noche. Los valores son promedios \pm $\mathrm{EE}(n=6$ plantas $)$.

InStANTANEOUS RATES OF $\mathrm{CO}_{2}$ uptake AND tOTAL DAILY Net $\mathrm{CO}_{2}$

With the exception of April 22-23, the highest Pn values were statistically higher for young cladodes under the wet condition than the dry condition for all dates of measurement (Fig. 4 a). The daily net $\mathrm{CO}_{2}$ uptake values were statistically higher under the wet condition than the dry condition only on May 14-15 and May 28-29. Watering increased the daily net $\mathrm{CO}_{2}$ uptake 3-fold from April 22-23 to May 14-15, whereas under the dry condition, the daily net $\mathrm{CO}_{2}$ uptake decreased from April 22-23 to May14-15. The increase in the daily net $\mathrm{CO}_{2}$ uptake from April to June was over 6fold for young cladodes under the wet condition and 5-fold for young cladodes under the dry condition (Fig. 4 b). The highest values of both $\mathrm{Pn}$ and daily net $\mathrm{CO}_{2}$ uptake in young cladodes occurred on June 25-26 under both the wet and dry conditions (Fig. 4 a, b). 


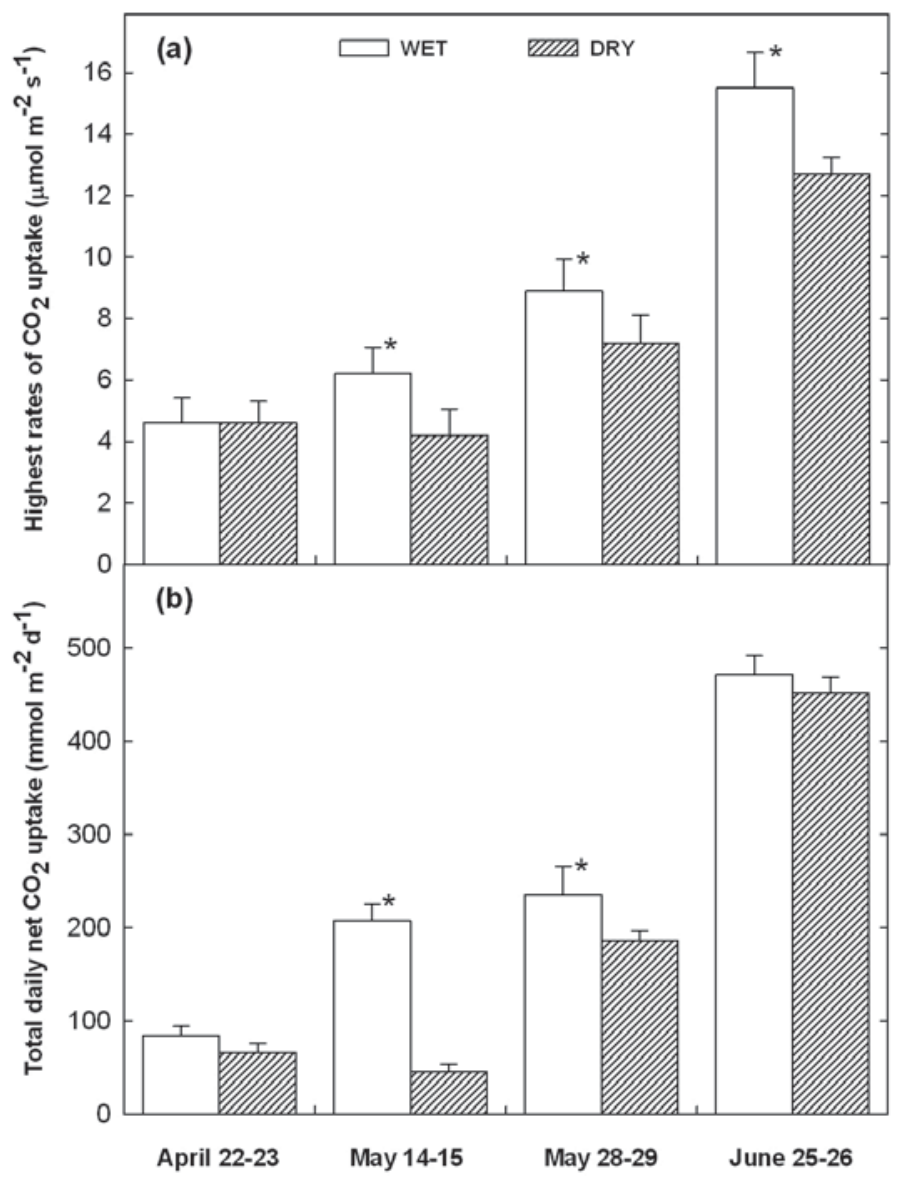

FIgURE 4. Highest rates of net $\mathrm{CO}_{2}$ uptake (a) and total daily net $\mathrm{CO}_{2}$ uptake (b) for young cladodes of $O$. ficus-indica on April 22-23, May 14-15, May 28-29 and June 25-26, under wet and dry conditions. Asterisks above the bars indicate statistically significant differences at $\mathrm{P}$ $<0.05$ by LSD multiple test.

Figura 4. Tasas más altas de asimilación neta de $\mathrm{CO}_{2}$ (a) y de asimilación neta diaria de $\mathrm{CO}_{2}$ (b) en cladodios jóvenes de $O$. ficus-indica el 22-23 de abril, 14-15 de mayo, 28-29 mayo y 25-26 de junio en condiciones húmeda y seca. Los asteriscos sobre las barras indican diferencias estadísticamente significativas a $\mathrm{P}<0,05$ en la prueba de DMS múltiple.

\section{DISCUSSION}

Succulence is an adaptive strategy that allows plants to remain active during seasonal water shortages (Eggli \& Nyffeler 2009, Ogburn \& Edwards 2010). It is considered one of the most efficient adaptations for maintaining carbon gain when CAM plants are exposed to prolonged drought (Griffiths et al. 2008, Herrera 2009). Here, we found that even though young cladodes showed the typical patterns of CAM plants, their low water-storage capacitance (water storage ability) was not sufficient to buffer the effects of drought stress when soil moisture is low. In contrast, $\mathrm{CO}_{2}$ uptake is maintained in mature organs when they are exposed to prolonged drought because of their large capacitance that allows tissue water content to remain relatively high, even when soil water content was low (Griffiths et al. 2008, Ogburn \& Edwards 2010, Pimienta-Barrios et al. 2000). Conversely, watering buffered the effects of drought on young cladodes, allowing them to sustain carbon gain in the dry spring season, playing the same role that succulence does on mature tissue of CAM plants (Mauseth 2006, Nobel 1995).

The increase in $\mathrm{Pn}$ and daily net $\mathrm{CO}_{2}$ uptake in young cladodes was most pronounced in June, after the plants had received substantial rainfall and root formation had increased in response to soil water availability. Because a significant portion of carbon fixed through photosynthesis is allocated to the maintenance and production of new roots, roots become a physiological carbon sink (Pregitzer et al. 1995). We suggest that the sharp increase in Pn observed for young cladodes in June under the wet condition and dry condition 
was caused by root sink strength because often the strength of the source (photosynthesis) is strongly influenced by sink demand (Muller et al. 2011). In addition, the increase in carbon uptake in June was favoured also by the occurrence of fresh day/night temperatures $\left(23 / 17^{\circ} \mathrm{C}\right)$, high day/night relative humidity, conditions that are favourable for $\mathrm{CO}_{2}$ uptake in opuntias (Nobel et al. 2002).

The increase in carbon gain in response to water availability for young cladodes under both the wet condition and dry condition occurs throughout the combination of both nighttime $\mathrm{CO}_{2}$ uptake (CAM pathway) and daytime $\mathrm{CO}_{2}$ uptake $\left(\mathrm{C}_{3}\right.$ pathway). Indeed, the partitioning of atmospheric $\mathrm{CO}_{2}$ between Rubisco of the $\mathrm{C}_{3}$ pathway during the day and phosphoenol pyruvate carboxylase of the CAM pathway during the night allows a flexible carboxylation capacity for young cladodes to maximise carbon gain when water is available (Cushman 2001). Young cladodes also show physiological plasticity when higher rates of $\mathrm{Pn}$ occurred just before the end of the night in the dry condition coinciding with high percentages of relative humidity and low temperatures, conditions leading to low transpiration thus avoiding the effects of drought.

All four phases of the CAM were observed for young cladodes under both the wet condition and dry condition, and they varied in terms of magnitude and duration. Young cladodes showed a plastic photosynthetic response in response to rains by increasing $\mathrm{CO}_{2}$ uptake at night (phase I), and they were able to supplement nocturnal $\mathrm{CO}_{2}$ uptake with daytime atmospheric $\mathrm{CO}_{2}$ assimilation (phase II and IV), which has been shown to be critical for optimising carbon gain in response to favourable conditions caused by rains (Dodd et al. 2002, Griffiths et al. 2008).

Because of the low water storage capacitance of young cladodes, drought stress leads to loss of phase IV under both the wet and dry conditions in late April as well as May1415 under the DC; but in mature cladode of O. ficus-indica $\mathrm{CO}_{2}$ uptake in phase IV is maintained when the soil water content was low, since their prominent succulence allows tissue water content to remain high (Nobel et al. 2002).

Phase IV was more affected than phase II, particularly under the dry condition because phase IV occurs late afternoon, coinciding with high irradiance, high temperatures and drought, conditions that prevailed in the dry spring at the study site and that favour carbon efflux throughout photorespiration (Maxwell et al. 1997, Foyer et al. 2009).

The photosynthetic efficiency of young cladodes was not far from the values observed in mature cladodes of opuntias. The daily net $\mathrm{CO}_{2}$ uptake value for mother cladodes of $O$. ficus-indica was $732 \mathrm{mmol} \mathrm{m}^{-2} \mathrm{~d}^{-1}$ (Pimienta-Barrios et al. 2000), compared with $472 \mathrm{mmol} \mathrm{m}^{-2} \mathrm{~d}^{-1}$ recorded for young cladodes under the wet conditions and $452 \mathrm{mmol} \mathrm{m}^{-2} \mathrm{~d}^{-1}$ under the dry conditions in June.

\section{CONCLUSIONS}

Although young cladodes showed CAM patterns, spring drought reduces significantly daily carbon gain; nevertheless they maintain positive values of carbon gain, notwithstanding the low capacitance of their water-storage parenchyma. On the other hand irrigation buffered the effects of spring drought on young cladodes, allowing them to sustain carbon gain. Young cladodes showed physiological flexibility that allows them to have important values of carbon gain, when drought is interrupted by rainfall. The increase in carbon gain in response to water availability for young cladodes under both the wet and dry conditions occurs throughout the combination of both nighttime $\mathrm{CO}_{2}$ uptake and daytime $\mathrm{CO}_{2}$ uptake.

\section{ACKNOWLEDGEMENTS}

We thank the students in the Fisiología Vegetal course for field assistance. We also thank Park S. Nobel and the reviewers for valuable comments on the manuscript.

\section{BIBLIOGRAPHY}

Acevedo, E., I. Badilla \& P.S. Nobel. 1983. Water relations, diurnal acidity changes and productivity of a cultivated cactus, Opuntia ficus-indica. Plant Physiology 72(3):775780.

Berlyn, G.P. \& J.P. Miksche. 1976. Botanical Microtechnique and Cytochemistry. The Iowa State University Press. Ames, Iowa. 326 pp.

Bravo-Hollis, H. 1978. Las Cactáceas de México, vol. 1. Universidad Nacional Autónoma de México. Mexico City. México. 743 pp.

Cushman, J.C. 2001. Crassulacean acid metabolism. A plastic photosynthetic adaptation to arid environments. Plant Physiology 127(4): 1439-1448.

Dodd, A.N., A.M. Borland, R.P. Haslam, H. Griffith \& K. MAXwell. 2002. Crassulacean acid metabolism: plastic, fantastic. Journal of Experimental Botany 53(369): 569580.

EgGLi, U. \& R. Nyffeler. 2009. Living under temporarily arid conditions-succulence as an adaptive strategy. Bradleya 27: 13-36.

Foyer, C.H., A.J. Bloom, G. Queval \& G. Noctor. 2009. Photorespiratory metabolism: genes, mutants, energetic, and redox signaling. Annual Review of Plant Biology 60: 455-484.

Griffiths, H., W.E. Robe, J. Girnus \& K. Maxwell. 2008. Leaf succulence determines the interplay between carboxylase systems and light use during Crassulacean acid metabolism in Kalanchoё species. Journal of Experimental Botany 59 (7): 1851-1861.

Hanscom, Z. \& I.P. Ting. 1978. Irrigation magnifies CAMphotosynthesis in Opuntia basilaris (Cactaceae). Oecologia 
Gas exchange of young cladodes of Opuntia ficus-indica: Pimienta-Barrios, E. ET AL.

33(1): 1-15.

Herrera, A. 2009. Crassulacean acid metabolism and fitness under water deficit stress: if not for carbon gain, what is facultative CAM good for? Annals of Botany 103(4): 645653.

Koide, R.T., R.H. Robichaux, S.R. Morse \& C.M. Smith. 2000. Plant water status, hydraulic resistance and capacitance. In: R.W. Pearcy, J. Ehleringer, H.A. Mooney \& P.W. Rundel (eds.), Plant Physiological Ecology, Field Methods and Instrumentation. pp. 161-178 pp. Kluwer Academic Publishers, Dordrecht, Netherlands.

Little, T. M \& J.F. Hill. 1975. Statistical Methods in Agricultural Research. University of California Press, Davis CA. EE.UU. 270 pp.

Mauseth, J.D. 2006. Structure-function relationships in highly modified shoots of cactaceae. Annals of Botany 98(5): 901-926.

Maxwell, K., S. von Caemmerer \& J.R. Evans. 1997. Is a low internal conductance to $\mathrm{CO}_{2}$ diffusion a consequence of succulence in plants with crassulacean acid metabolism? Australian Journal of Plant Physiology 24(6): 777-786.

Muller, B., F. Pantin, M. Génard, O. Turc, S. Freixes, M. Piques \& Y. Gibon. 2011. Water deficits uncouple growth from photosynthesis, increase $\mathrm{C}$ content, and modify the relationship between $\mathrm{C}$ and growth in sink organs. Journal of Experimental Botany 62(6): 1715-1729.

NoBel, P.S. 1994. Remarkable Agaves and Cacti. Oxford University Press. New York, NY. 166 pp.

NoBel, P.S. 1995. Environmental biology. In: G. Barbera, P. Inglese, E. Pimienta-Barrios (eds.), Agroecology, Cultivation and Uses of Cactus Pear. pp: 36-48. FAO International Technical Cooperation Network on Cactus Pear. Rome, Italy.
Nobel, P.S., E. Pimienta-Barrios, J. Zañudo-Hernández \& B.C. RAmíreZ-Hernández. 2002. Historical aspects and net $\mathrm{CO}_{2}$ uptake for cultivated Crassulacean acid metabolism plants in Mexico. Annals of Applied Biology 140(2): 133-142.

Ogburn, R.M. \& E.J. Edwards. 2010. The ecological water-use strategies of succulent plants. In. J.C. Kader \& M. Delseny (eds.), Advances in Botanical Research. Vol. 55. pp. 179225. Academic Press. Burlington, USA.

Osmond, C.B. 1978. Crassulacean acid metabolism: A curiosity in context. Annual Review of Plant Physiology 29: 379-414.

Pimienta-Barrios, Eu., J. Zañudo, E. Yepez, En. Pimienta-Barrios \& P.S. Nobel. 2000. Seasonal variation of net $\mathrm{CO}_{2}$ uptake for cactus pear (Opuntia ficus-indica) and pitayo (Stenocereus queretaroensis) in a semi-arid environment. Journal of Arid Environments 44(1): 73-83.

Pregitzer, K.S., D.R. ZAK, P.S. Curtis, M.E. Kubiske, J.A. Teeri \& C.S. Vogel. 1995. Atmospheric $\mathrm{CO}_{2}$, soil nitrogen and turnover of fine roots. New Phytologist 129: 579-585.

Szarek, S.R. \& I.P. Ting. 1975. Physiological responses to rainfall in Opuntia basilaris (Cactaceae), American Journal of Botany 62(6): 602-609.

Torres, R.E. 1984. Manual de Conservación de Suelos. Diana Publishing, Mexico City. 170 pp.

Wang, N., H. Zhang \& P.S. Nobel. 1997. Phloem-xylem water flow in developing cladodes of Opuntia ficus-indica during sink-to-source transition. Journal of Experimental Botany 48(3): 675-682.

Winter, K., M. García \& J.A.M. Holtum. 2008. On the nature of facultative and constitutive CAM: environmental and developmental control of CAM expression during early growth of Clusia, Kalanchoë, and Opuntia. Journal of Experimental Botany 59(7): 1829-1840.

ZAR, J.H. 1999. Biostatistical Analysis. Four ed. Prentice Hall, New Jersey. USA. 663 pp.

Recibido: 07.03.12

Aceptado: 11.06.12 